\title{
Praca w nauczaniu Jana Pawła II. Treści partykularne i uniwersalne
}

\section{Uniwersalność i partykularność nauczania społecznego Kościoła}

Nie wchodząc w spory wokół statusu metodologicznego nauczania społecznego Kościoła (NSK) i katolickiej nauki społecznej (KNS)1 przyjmujemy, że obejmują one m.in. treści etyczne - normatywne. Jako takie są one uniwersalne. Już Immanuel Kant wiedział, że możliwość generalizacji (uniwersalizacji) jakiejś normy - to, „aby stała się prawem powszechnym” - jest kryterium jej etyczności. Jednocześnie trudno zaprzeczyć konieczności „inkulturacji” standardów etycznych.

Dlatego też obowiązujące hic et nunc standardy etyczne są zawsze konkretne - kulturowo zróżnicowane. Wydaje się, że - niezależnie od współczesnego pluralizmu ideowego - troska o takie zintegrowanie elementów uniwersalności i partykularności w standardach etycznych, aby nie popadać ani w moralny absolutyzm, ani w moralny relatywizm jest postawą dominującą w środowiskach etycznych. Ich przedstawiciele doskonale wiedzą, że plastyczność aplikacji zasad nie oznacza relatywizacji, lecz konkretyzację².

"Prof. dr hab. Aniela Dylus, Instytut Politologii, Wydział Nauk Historycznych i Społecznych, Uniwersytet Kardynała Stefana Wyszyńskiego, 01-938 Warszawa, ul. Wóycickiego 1/3.

${ }^{1} \mathrm{Na}$ ten temat por.: H. JuRos, Miejsce katolickiej nauki społecznej w polskiej typologii nauk, [w:] Dyskryminacja jako nowa kwestia społeczna, red. J. Kupny, A. Dylus, T. Biedrzycki, Katowice 2007, s. 11-25; idem, Katolicka nauka społeczna 2010, [w:] Od akcesji do prezydencji. Kościół katolicki w Polsce i Unia Europejska, red. P. Burgoński, S. Sowiński, Toruń 2011, s. 197-225; J. Gocko, Nauka społeczna Kościoła w poszukiwaniu własnej tożsamości, Warszawa 2013.

${ }^{2} \mathrm{O}$ tej regule przypomniał Paweł Bortkiewicz, omawiając kwestię komunikowania prawdy człowiekowi umierającemu. Por. P. BoRTKIEwICz, Tanatologia. Zarys problematyki moralnej, Poznań 2000, s. 222. 
Dotyczy to także przepowiadania Kościoła. Przecież definiuje się on jako i powszechny, i lokalny. Rzeczywiście, uniwersalność i partykularność są niezbywalnymi atrybutami Kościoła. Jego nauczanie opiera się na powszechnie ważnym prawie naturalnym i jest skierowane do całej rodziny ludzkiej, do wszystkich ludzi dobrej woli. Jednocześnie warunkiem recepcji tego nauczania jest odniesienie treści przekazu do spraw ważnych dla wspólnoty lokalnej „tu i teraz”. Trudno też nie zauważyć sytuacyjnego piętna, którym naznaczone są dokumenty NSK. W konsekwencji odwołującą się do tego nauczania KNS definiuje się jako „system zdań otwartych”. Owszem, jest to najpierw pewien „system”, na który składają się niezmienne zasady chrześcijańskiej etyki społecznej. Ich bezcenny potencjał porządkujący życie społeczne daleki jest od wyczerpania. Świadczy o tym chociażby kariera, jaką w ostatnich dziesięcioleciach zrobiła zasada pomocniczości. Niemniej ów system zasad ciągle trzeba uzupełniać nowymi treściami. Jest on jedynie pewnym drogowskazem, nie zaś receptą na idealny ustrój społeczny, choć kolejni ideologowie łudzą takimi obietnicami. Wszystko to oczywiście odnosi się także do nauczania na temat pracy.

\section{Treści partykularne w encyklice Laborem exercens}

Jak w każdej encyklice, tak i w Laborem exercens (LE) z treściami ponadczasowymi sąsiadują treści uwarunkowane historycznie, które zresztą sam Jan Paweł II uzupełniał w kolejnych swoich encyklikach społecznych: Sollicitudo rei socialis (SRS) i Centesimus annus (CA). Warto przypomnieć dramatyczny kontekst ogłoszenia pierwszej encykliki społecznej tego papieża. Choć jest ona adresowana do całego Kościoła powszechnego, do wszystkich ludzi dobrej woli, widać w niej piętno polskich doświadczeń. Rok 1981 to w ojczyźnie Ojca Świętego rok pełen nadziei, choć wyjątkowo niespokojny. Od kilku miesięcy istnieje zarejestrowany oficjalnie Niezależny Samorządny Związek Zawodowy „Solidarność”, czyli pierwszy poważny wyłom w monolicie komunistycznego „bloku wschodniego”. Wielki społeczny ruch odrodzenia moralnego objął 10 milionów ludzi. Chwieją się fundamenty imperium. Rozwój wypadków po raz kolejny zdaje się potwierdzać tezę obecną już wcześniej na kartach encyklik: „praca jest kluczem do kwestii społecznej”. Okazało się mianowicie, że nieposzanowanie pracy, permanentne naruszanie słusznych uprawnień ludzi pracy, stworzenie ustroju, w którym jej owoce są marnowane - rodzi protest zdolny wstrząsnąć „murami”. Niemniej wydaje się, że sposób przywołania tej tezy zdradza już pewne wahanie Jana Pawła II. Pisząc bowiem o wyjątkowym znaczeniu pracy ludzkiej, zastrzega, że jest to „chyba [podkr.: A.D.] najistotniejszy klucz do całej kwestii społecznej” (LE 12).

Rzeczywiście, identyfikacja różnych palących „kwestii” i określenie ich rdzenia jest historycznie zmienne. Jak wiadomo, u Leona XIII w Rerum novarum była to „kwestia robotnicza”, od Quadragesimo anno mowa jest o „kwestii społecznej”. 
W Veritatis splendor Jan Paweł II kieruje naszą uwagę na „kwestię kulturową”, zaś Benedykt XVI - mówiąc o "nowej kwestii społecznej” - wskazuje na jeszcze inny obszar problemowy, wręcz przesądzający dziś o naszym „być” albo „nie być”. Upomina się mianowicie o ochronę prawa do życia, ochronę instytucji rodziny opartej na małżeństwie, ochronę praw rodziców do utrzymywania i wychowania dzieci oraz praw dziecka do naturalnej rodziny.

W każdym razie trzydzieści lat, jakie w 2011 r. upłynęło od ogłoszenia LE, to na przełomie wieku XX i XXI okres bardzo długi. Tym bardziej, że globalizacja, która w ostatnich kilku dekadach objęła procesy gospodarcze, oznacza przyspieszenie w wielu dziedzinach. Sądzę, że w swej „zmiennej” warstwie treściowej jest LE ostatnią wielką encykliką społeczną epoki industrialnej, tj. epoki, w której o porządku gospodarczym albo o chaosie, sprawiedliwości albo niesprawiedliwości przesądza relacja między pracą i kapitałem, zaś konflikt między tymi czynnikami może prowadzić do społecznego wybuchu. Konflikt ten przybiera przy tym różne formy w dwóch konkurencyjnych systemach: socjalizmu i kapitalizmu.

W dziejach myśli ekonomicznej wielokrotnie modyfikowano i uzupełniano tę wywodzącą się jeszcze od Adama Smitha enumerację podstawowych czynników produkcji (obok pracy i kapitału zalicza się tu jeszcze ziemię). Sam Jan Paweł II wspomina o przedsiębiorczości (w SRS) oraz o kapitale intelektualnym (w CA). Trzeba zaznaczyć, że w LE pojęcie kapitału jest dość wąskie. Obejmuje jedynie kapitał rzeczowy, tj. zasoby natury oraz zespół środków produkcji (por. LE 12).

Jak wiadomo, w poszczególnych epokach rozwoju gospodarczego zmienia się waga poszczególnych czynników produkcji. Podczas gdy w epoce feudalnej podstawowym czynnikiem jest ziemia, w kapitalizmie industrialnym - praca i kapitał, to w okresie postindustrialnym wiodącym czynnikiem okazuje się wie$\mathrm{dza}^{4}$. W konsekwencji - spada znaczenie przemysłu w gospodarce, rośnie zaś znaczenie usług. Oczywiście, wraz z serwicyzacją gospodarki stępione zostaje ostrze starego konfliktu między pracą a kapitałem. Bez wątpienia też przybiera on inne formy.

\section{Treści uniwersalne w nauczaniu o pracy}

Ponadczasowe - powszechne i uniwersalne treści LE dotyczą „poziomu” antropologii etycznej i teologicznej - podstawowych zasad społeczno-etycznych czy praw człowieka. Zanim podejmiemy próbę rekonstrukcji ich treści warto wskazać na szerokie ujmowanie pracy przez Jana Pawła II.

${ }^{3}$ Szerzej na ten temat por.: H. JuRos, „Kwestia kulturowa” w encyklice „Veritatis splendor”, [w:] idem, Kościót. Kultura. Europa, Lublin-Warszawa 1997, s. 83-102.

${ }^{4}$ Por. P. Drucker, Społeczeństwo pokapitalistyczne, Warszawa 1999. 


\subsection{Szerokie ujęcie pracy}

Ciekawe, że w encyklice o pracy właściwie nie znajdujemy definicji tej kluczowej kategorii. Sformułowanie: „praca zaś oznacza każdą działalność, jaką człowiek spełnia, bez względu na jej charakter i okoliczności, to znaczy każdą działalność człowieka, którą za pracę uznać można i uznać należy pośród całego bogactwa czynności, do jakich jest zdolny i dysponowany poprzez samą swoją naturę, poprzez samo człowieczeństwo" (LE, Wstęp) trudno przecież uznać za definicję pracy.

Ta szerokość i niedookreśloność ujęcia pracy okazuje się przy tym czymś niezwykle cennym. Jan Paweł II uniknął w ten sposób pułapki potocznego jej ujmowania, tj. utożsamiania pracy wyłącznie z jedną spośród jej form - z pracą najemną. Jeśli mniej uważny bezrobotny, tj. pozbawiony pracy najemnej, czytelnik LE przeoczy ten fakt, może popaść w wielkie przygnębienie. Tym bardziej, że prognozy dotyczące społeczeństwa pokapitalistycznego przewidują w przyszłości permanentny deficyt „pracy najemnej”’ Powodem frustracji może mianowicie stać się zdanie, że dzięki pracy człowiek „poniekąd bardziej «staje się człowiekiem»” (LE 9). Jeśli zaś z pracą wiąże się wyłącznie zajęcie na etacie, to trudno się dziwić temu poczuciu degradacji. Bezrobocie okazuje się wtedy klęską nie tylko zawodową, ale człowieczą - egzystencjalną. Brak pracy oznacza przecież degradację własnego człowieczeństwa, wykluczenie możliwości stawania się „bardziej człowiekiem”. W kontekście przytoczonego wyżej szerokiego określenia pracy wniosek taki jest jednak zupełnie bezzasadny. Pracą jest przecież nie tylko praca najemna, ale i samozatrudnienie, praca polegająca na samokształceniu, praca w gospodarstwie domowym (wychowywanie dzieci, prace opiekuńcze, sprzątanie, renowacje itp.), wolontariat.

Uniwersalne treści etyki gospodarczej obecne w NSK dotyczą jednak kwestii najbardziej podstawowych: istoty oraz sensu pracy i w ogóle całego życia gospodarczego.

\subsection{Antropocentryczna teleologia pracy}

Syntetyczną formułę pożądanego ukierunkowania gospodarki, do której nawiązują następnie kolejne encykliki społeczne, znajdujemy chociażby w soborowej Konstytucji duszpasterskiej o Kościele w świecie współczesnym (KDK) Gaudium et spes: „Człowiek bowiem jest twórcą, ośrodkiem i celem całego życia gospodarczo-społecznego” (KDK 63). Wszelkie zatem zabiegi wokół „czynienia sobie Ziemi poddaną" mają naprawdę głęboko humanistyczny i wspólnototwórczy sens.

Natomiast wolny rynek został uznany za „najbardziej skuteczne narzędzie wykorzystywania zasobów i zaspokajania potrzeb” (CA 34). Owszem, jest to „najbardziej skuteczne”, ale zaledwie „narzędzie”. Zdecydowane akcentowanie podmiotowości

${ }^{5}$ Por. J. RIFkIN, Koniec pracy. Schyłek siły roboczej na świecie i początek ery postrynkowej, Wrocław 2001. 
człowieka w życiu gospodarczym, jego pierwszeństwa przed rzeczą (por. np. LE 12) należy zresztą do uniwersalnych kanonów kultury europejskiej. Do tego sprowadza się przecież Kantowski imperatyw kategoryczny (w swej wersji materialnej), że człowieka należy traktować zawsze zarazem jako cel, nigdy tylko jako środek.

Bodaj najcenniejszym, uniwersalnym elementem treściowym LE są właśnie filozoficzne (i teologiczne) rozważania na temat istoty pracy, jej podmiotowego charakteru, pierwszeństwa w stosunku do kapitału itp. Wszystko to mieści się w kategorii godności pracy. Choć wiele już napisano na ten temat ${ }^{6}$, warto ponowić próbę eksplikacji tego pojęcia.

\subsection{Godność pracy}

W katalogu fundamentalnych, uniwersalnych pojęć personalistycznych znajdujemy nie tylko pojęcie godności człowieka - osoby, lecz także godności ludzkiej pracy. W kręgu myśli chrześcijańskiej zostało ono upowszechnione głównie dzięki omawianej tu encyklice LE. Bynajmniej nie chodzi przy tym o socjologiczną kategorię honoru ludzi pracy jako pewnej grupy społecznej (honor zawodowy górnika, kolejarza, nauczyciela itp.). Treść pojęcia godności pracy jest dużo głębsza.

\subsubsection{Praca jako dobro godziwe}

Pracy ludzkiej przysługuje godność najpierw dlatego, że jest ona jednym z czynników przesądzających o godności człowieka, o jego wyróżnionej pozycji wśród innych bytów. Właśnie zdolność jej wykonywania nobilituje istotę ludzką. W skrajnych ujęciach marksistowskiej filozofii pracy wyłącznie dzięki procesowi pracy, a zwłaszcza konstruowaniu narzędzi i posługiwaniu się nimi, nastąpił proces hominizacji, czyli ewolucyjnego wyłaniania się człowieczeństwa.

Jednak w personalistycznym kontekście myślowym akcentuje się raczej inną zależność. Praca uzyskuje godność dzięki godności wykonującego ją człowieka. To godność podmiotu jest miarą godności pracy. Nie da się oddzielić procesu pracy i jej efektu od człowieka pracującego. On jest twórcą i sprawcą czynu pracy. Wyciska osobowe piętno - niezatarte znamię - na tym, co robi. Odwołując się do terminologii LE, ów „podmiotowy wymiar” pracy przesądza o tym, że praca

${ }^{6}$ Wokół encykliki LE narosła dość obszerna literatura: komentarze, opracowania, polemiki, monografie. Spośród polskich publikacji jedynie tytułem przykładu można wymienić: Cz. BARTNIK, Ręka i myśl. Teologia pracy, odpoczynku i świętowania, Katowice 1982; Ewangelia pracy. Encyklika Jana Pawła II "Laborem exercens” wraz z komentarzem, red. J. Chmiel, S. Ryłko, Kraków 1983; JAN PAWEt II, „Laborem exercens”. Powołany do pracy, red. J. Krucina, Wrocław 1983; J. TischneR, W kręgu filozofii pracy, Kraków 1983; JAN PAWEt II, „Laborem exercens”. Tekst i komentarz, red. J. Gałkowski, Lublin 1986; J. MAJKA, Rozważania o etyce pracy, Wrocław 1986.

${ }^{7}$ Kluczowe pojęcia LE zostały wypracowane już wcześniej. Odnajdujemy je np. w książce K. WoutyŁy Osoba i czyn, Kraków 1968. Chodzi tu zwłaszcza o przewodnią ideę tego dzieła: „czyn - objawieniem osoby". 
jest dobrem nie tylko „ «użytecznym» czy «użytkowym», ale dobrem «godziwym», czyli odpowiadającym godności człowieka, wyrażającym tę godność i pomnażającym ją" (LE 9).

\subsection{2. „Zadana” godność pracy}

Praca jako dobro godziwe jest jednocześnie kategorią normatywną. Wartość zawsze przecież domaga się realizacji. Można powiedzieć, że godność pracy jest człowiekowi „zadana”. Jako taka jest jego powinnością (obowiązkiem), jak i prawem (uprawnieniem). Oczywiście, „zadanie” realizacji godności pracy jest podmiotowo zróżnicowane, zależnie od możliwości fizycznych i psychicznych, od zdolności i upodobań jednostki.

Adresatem zadania (powinności) wypełnienia godności pracy jest najpierw osoba samego pracującego. Właśnie wobec siebie ma ona chociażby obowiązek samodzielnego pozyskiwania środków utrzymania oraz rozwoju osobowego. Obowiązek ten jest uzasadniony powinnością jeszcze bardziej podstawową: podtrzymywania swego życia. Uczestnictwo w procesie pracy wymaga twórczej inwencji, przedsiębiorczości, odwagi, wytrwałości, uczciwości, pilności i wielu innych cnót. Dzięki pracy człowiek ma szansę samorealizacji, „pomnożenia” swej godności. Może stać się lepszy, odkryć i dobrze wykorzystać drzemiące w nim talenty. Tym bardziej, że praca jest bonum arduum.

Niezależnie od jej rodzaju, techniki i organizacji (praca w znaczeniu przedmiotowym), zawsze towarzyszy jej trud. Wykonuje się ją „w pocie czoła”. Wysiłek fizyczny i umysłowy, będący wynikiem oporu tworzywa, przeszkód, na jakie napotyka człowiek w procesie pracy, konieczności dostosowania się do wymuszonego rytmu i dyscypliny pracy, niedogodności związanych z zespołowym wykonywaniem wielu czynności itp. - bynajmniej nie eliminuje radości, która również wiąże się z pracą. Jej źródłem jest właśnie wspomniana już możliwość twórczości, rozwijania w trakcie pracy sił duchowych i fizycznych, szansa "sprawdzenia się", zużytkowania nagromadzonych energii i wcielenia ich w wykonywane dzieło.

Praca jako dobro godziwe ma dalej „odpowiadać” godności innych osób zaangażowanych w ten proces, ma „wyrażać” i „pomnażać” ich godność - jak to napisano w Laborem exercens. Rdzeniem i ostatecznym celem pracy jest zaspokajanie ludzkich potrzeb. Konstytucja psychofizyczna człowieka domaga się ciągłego ich zaspokajania, a zatem praca ostatecznie jest służbą człowiekowi, autentyczną formą miłości bliźniego. Jej owoce służą pozostającym na utrzymaniu pracownika członkom jego rodziny oraz wszystkim innym odbiorcom wytworów pracy. Chodzi przy tym o bezpośrednich konsumentów, o tych, którzy jeszcze w przyszłości będą korzystać z trwałych dóbr materialnych i kulturalnych, powstających w wyniku pracy obecnego pokolenia. Odpowiedzialne gospodarowanie zasobami naturalnymi, wzgląd na problemy ekologiczne jest ważnym obowiązkiem wobec przyszłych pokoleń. 
O tym, że praca jest zawsze pracą „dla kogoś” trafnie i pięknie pisał niegdyś Józef Tischner: „praca to rozmowa w służbie życia”. Właśnie dzięki wartości życia, której służy praca, uzyskuje ona wartość i godność. W dobie dominacji „pracy chorej" filozof próbował postawić diagnozę tej choroby. Otóż praca choruje, a nawet przestaje być pracą, gdy zamiast życia przynosi uwiąd i śmierć oraz gdy jej uczestnicy kłamią. Kłamstwem zaś pracy jest wyzysk. Praca wyzyskiwana, fałszywa nie tworzy, a dzieli9.

Metafora rozmowy świetnie też pokazuje, że praca jest zawsze pracą „Z kimś”. Zwłaszcza w sytuacji daleko posuniętego podziału pracy końcowy jej wytwór stanowi często efekt wielorakich współzależności; rezultat współdziałania wielu ludzi i wielu ogniw wytwórczych. Podmiot pracy ma więc także określone powinności wobec tej wielkiej „wspólnoty wytwarzania”: wobec bezpośrednich współpracowników (koledzy, przełożeni, podwładni) i wobec kooperantów. W obrębie tej wspólnoty zobowiązany jest chociażby do solidarności, współpracy, gospodarności, sumienności, koleżeństwa, lojalności itp. Co więcej, mając na uwadze wspólnototwórczy i kulturotwórczy wymiar procesu pracy, (współ) odpowiedzialność podmiotu za realizację „zadanej” godności pracy sięga jeszcze dalej: całego narodu, społeczeństwa czy nawet cywilizacji i kultury pracy społeczności międzynarodowej.

Wspomniano już o możliwości upodlenia ludzi pracy: o fałszu pracy, wyzysku, „służbie śmierci”. Zadanie realizacji (relatywnej) godności pracy okazuje się prawie nieosiągalne dla tych wszystkich, którzy na własnej skórze doświadczyli pracy ponad siły, źle zorganizowanej, nużącej, monotonnej, ogłupiającej, bezsensownej, niesprawiedliwie opłaconej, a w końcu - degradującej. Dotyczy to chociażby pracowników najemnych, zatrudnionych w systemie taśmowym, pracowników źle opłacanych, dręczonych, zastraszanych ${ }^{10}$. Wprawdzie w najgłębszym, metafizycznym sensie i ich praca jest „dobrem godziwym”, ale obowiązkiem wszystkich odpowiedzialnych za organizację procesu pracy jest humanizacja jej warunków, a szerzej - kształtowanie godnościowego ładu pracy.

\footnotetext{
8 J. Tischner, Etyka solidarności, Kraków 1981, s. 19.

${ }^{9}$ Por. ibidem, s. 21.

${ }^{10}$ Okazuje się, że tzw. praca przymusowa (ściśle rzecz biorąc, to pojęcie jest sprzeczne samo w sobie, skoro do istoty pracy należy wolne jej wykonywanie), wręcz niewolnicza, połączona ze skrajnym wyzyskiem pracowników, ma miejsce nie tylko w systemach totalitarnych. Mimo niekwestionowanych osiągnięć socjalnych i poprawy warunków zatrudnienia w ostatnim stuleciu, sytuacje niewolniczego wyzysku zdarzają się i współcześnie. Dochodzi do nich m.in. w tzw. sweatshops, czyli przedsiębiorstwach osiągających zyski z potu swoich pracowników, zmuszanych do długotrwałego wysiłku za niewielkie wynagrodzenie i w warunkach urągających godności człowieka. Choć przedsiębiorstwa tak skandalicznie traktujące pracowników spotyka się głównie w Chinach, Indiach czy państwach rozwijających się, to niekiedy media ujawniają występowanie przypadków bulwersującego wyzysku pracowników i w Europie. O sweatshops-ach przejmująco pisze A. LeWICKA-STRZAkECKA, Sweatshops: czynnik ekonomicznego rozwoju czy instrument wyzysku?, [w:] Wyzysk ekonomiczny współcześnie, red. K. Sosenko, Kraków 2007, s. 179-193.
} 


\subsubsection{Godnościowy ład pracy}

Odwołując się do omawianej tu encykliki, można podać pewne ogólne zasady, które tkwią u podstaw takiego ładu, chociażby zasadę prymatu człowieka wobec rzeczy i pracy przed kapitałem (por. LE 12). W punkcie wyjścia godnościowego ładu pracy winny się też znaleźć takie ogólne maksymy jak np.:

- praca jest zawsze „dla człowieka”, a nie człowiek „dla pracy”;

- traktuj każdego człowieka według podmiotowej wartości jego pracy.

Wskutek skomplikowanego splotu gospodarczych współzależności proces pracy często jest trudny do zgłębienia. Brak możliwości przeniknięcia nieprzejrzystego systemu, postrzeganie siebie jako mało ważnego elementu bezosobowej całości, jako przysłowiowego trybiku w wielkiej maszynerii okazuje się doświadczeniem niezwykle alienującym. Pracownikom trzeba wówczas ułatwić zrozumienie sensu tego, co robią. Wydaje się, że na tym właśnie polega jedno z głównych zadań tzw. humanizacji pracy. Ogólnie rzecz biorąc, obejmuje ona zespół przedsięwzięć dla ukształtowania takiego kontekstu procesu pracy, który sprzyja „pomnożeniu" godności człowieka. Chodzi m.in. o to, aby nawet pracownik najemny miał poczucie, że pracuje „na swoim” (por. LE 15). Oczywiście, nie bez znaczenia dla tego poczucia jest ustrój własności, a przynajmniej możliwość współudziału szerokiego kręgu osób we własności produkcyjnej. 